\title{
Seasonal variation in serum testosterone, testicular measurements and semen characteristics in the collared peccary (Tayassu tajacu)
}

\author{
E. C. Hellgren $\dagger$, R. L. Lochmiller, M. S. Amoss, Jr*, S. W. J. Seager*, \\ S. J. Magyar*, K. P. Coscarelli* and W. E. Grant
}

Department of Wildlife and Fisheries Sciences and ${ }^{*}$ Department of Veterinary Physiology and Pharmacology, Texas A\&M University, College Station, TX 77843, USA

\begin{abstract}
Summary. Blood samples and testicular measurements were obtained from 4-8 captive adult collared peccaries monthly for 18 months and from wild adult males during summer $(\mathbf{N}=16)$ and winter $(\mathbf{N}=22)$ seasons. Serum concentrations of testosterone were determined by radioimmunoassay. Semen samples were collected monthly by electroejaculation from captive males for 1 year. Serum testosterone concentrations and testicular measurements varied in a low-amplitude circannual pattern, with maximum mean testosterone concentrations in fall and winter $(1150-1400 \mathrm{pg} / \mathrm{ml})$ and minimum values in summer $(500-700 \mathrm{pg} / \mathrm{ml})$. Circannual rhythms appeared to be related to dominance. Serum testosterone levels in wild males generally were lower than in captive males, although this difference was not significant $(P>0.05)$. Semen characteristics did not exhibit a circannual rhythm. These results suggest that the male peccary remains reproductively fertile throughout the year, yet may undergo a facultative summer quiescence influenced by ambient temperature and social factors.
\end{abstract}

Keywords: collared peccary; dominance; reproduction; seasonality; semen; testosterone

\section{Introduction}

The collared peccary (Tayassu tajacu) is a social ungulate which ranges from the American southwest, through the tropics, into northern Argentina. Reproductive biology of the male collared peccary remains largely unexplored, although female reproduction has been studied in detail (Wislocki, 1931; Sowls, 1966; Low, 1970; Smith \& Sowls, 1975; Lochmiller, 1984; Lochmiller et al., 1984b; Hellgren et al., 1985). Field studies have shown strong relationships between vegetative quantity and quality, rainfall, and peccary herd recruitment (number of young surviving to breeding age) (Low, 1970; Bissonette, 1982). Female peccaries are capable of producing young all year, yet peak breeding occurs in winter, culminating in late spring-early summer parturition (Low, 1970; Ellisor \& Harwell, 1979; Bissonette, 1982). Field (Low, 1970; Bissonette, 1982) and experimental (Lochmiller et al., 1986) studies suggest that summer and fall nutrition affect female breeding activity, reducing herd recruitment during periods of drought-induced nutritional stress.

The role of the male peccary in affecting herd recruitment is unknown. Low (1970) failed to demonstrate a circannual reproductive rhythm in his investigation of testicular weights and histology (tubule diameter, spermatozoa per tubule, percentage tubules). However, he proposed that high ambient temperatures or nutritional stress, induced by drought or decreases in proteinaceous forage during late summer, may reduce male breeding activity to mirror female acyclicity (Low,

†Present address: Caesar Kleberg Wildlife Research Institute, Texas A\&M University, Kingsville, TX 78363, USA. 
1970; Lochmiller et al., 1986). Lochmiller et al. (1985) reported decreases in serum testosterone values and scrotal circumference in peccaries following 9 weeks of nutritional restriction. The aims of the present study were to profile the annual rhythm in serum testosterone, testicular measurements and semen characteristics in male peccaries, to compare testosterone concentrations between wild and captive individuals, and to suggest the role of the male in the regulation of reproduction.

\section{Materials and Methods}

Animal handling and sampling. All captive animals were obtained from south Texas from the Chaparosa Ranch in Zavala County or the Chaparral Wildlife Management Area (CWMA) in Dimmit and LaSalle Counties. They were housed in a $900-\mathrm{m}^{2}$ outdoor enclosure on the campus of Texas A\&M University. A commercial hog ration (16\% crude protein and $3300 \mathrm{kcal} / \mathrm{kg}$ digestible energy) and water were provided ad libitum. Monthly anthelmintic treatments with levamisole hydrochloride were also provided. Free-ranging male peccaries were trapped on the Chaparosa Ranch and the CWMA during summer 1982 (July-August) and winter 1983 (February-March) in modified Clover deer traps baited with whole corn $(\mathrm{N}=44)$ or gun-shot through the spine $(\mathrm{N}=3)$.

Blood samples were collected at monthly intervals from four adult ( $>18$ months) male peccaries housed in a $15 \mathrm{~m} \times 30 \mathrm{~m}$ section of the enclosure starting in August 1982. Five additional males (4 adult, 1 subadult) were introduced into the enclosure in March 1983 and sampled initially following a 2-week acclimatization period. The subadult was aged at approximately 9 months by tooth eruption (Kirkpatrick \& Sowls, 1962) upon introduction to the pens. Monthly sampling continued until March 1984 with the exceptions of December 1982 and January 1984. Males had olfactory and visual contact with cyclic females throughout the study. However, tactile contact (through a fence) occurred only during October-November 1982 and June 1983. Dominance was determined on incidental pen observations, based on behaviours described by Schweinsburg \& Sowls (1972) and Sowls (1974). During August to October 1983, animals were housed individually in $2 \mathrm{~m} \times 3 \mathrm{~m}$ pens as part of another experiment. Before handling, animals were herded into a centrally located holding pen and immobilized by intramuscular injection of ketamine hydrochloride $(20 \mathrm{mg} / \mathrm{kg}$ ) administered by blow-gun dart syringe (Lochmiller \& Grant, 1983). Blood was obtained by anterior vena cava puncture (Lochmiller et al., 1984a) between $08: 00$ and 12:00 h on the day of collection. Samples were allowed to clot for $1 \mathrm{~h}$ in 10-ml Vacutainer tubes, chilled in an ice water bath, and centrifuged for 15-20 min. Serum was then drawn off and frozen at $-20^{\circ} \mathrm{C}$ for later analysis. Immobilization and blood sampling procedures were identical for free-ranging peccaries, except for the 3 free-ranging peccaries collected by gun-shot. Cardiac puncture within $5 \mathrm{~min}$ of death was used to collect blood from these individuals. Serum testosterone concentrations (see below) of gun-shot individuals were within the range of values for trapped/anaesthetized individuals.

From February 1983 to March 1984, semen was collected by electroejaculation at monthly intervals from 4-8 captives. All males were sexually rested for at least 2 weeks before collections. Semen collection usually was performed immediately after blood sampling while the animals were still immobilized, as described by Seager et al. (1984). The preputial area was shaved and washed before collection to prevent contamination of the ejaculate. Scrotal circumference was measured using a flexible cloth tape. Testicular length, testicular width and combined testicular width were recorded with vernier calipers after drawing scrotal skin tightly over the testis. Body weight was measured to the nearest $0 \cdot 1 \mathrm{~kg}$ using a dial scale.

Immediately after collection, a drop of semen was placed on a prewarmed slide and a visual estimate of motility (\% motile spermatozoa) and progressive motility (rate of progressive movement on a scale of $0-5,5$ being optimum) was made. The ejaculate then was placed in a graduated centrifuge tube in a $37^{\circ} \mathrm{C}$ water bath and liquid and gel volume recorded. Sperm concentration was estimated after dilution using a haemocytometer and total sperm count was calculated by multiplying sperm concentration by liquid volume. A minimum of 200 spermatozoa was examined for gross morphology using wet, unfixed samples. Sperm morphological types were placed into 4 categories for ease of data handling (R. G. Saacke, personal communication): normal spermatozoa, head abnormalities (acrosomal defects, micro- and macrocephaly), droplet abnormalities (proximal or distal protoplasmic droplets), and tail abnormalities (coiled tails, bent tails, and abaxial tail attachment). Two observers (S.J.M., E.C.H.) made all subjective estimates of semen characteristics.

Hormone assay. Testosterone concentrations were assayed in serum by radioimmunoassay of $50 \mu \mathrm{l}$ samples in duplicate as described by Abraham et al. (1971). Serum was extracted with $4 \mathrm{ml}$ ethyl ether. The anti-testosterone antibody was purchased from Cambridge Medical Diagnostics Inc. (R51226F) (Billerica, MA 01865, USA). Crossreactivity was determined to be $<0 \cdot 1 \%$ for all steroids tested except dihydrotestosterone, $3 \beta, 11 \beta$-dihydroxy-5 $\alpha$ androstan and androstenedione, which had cross-reactions of $21 \cdot 0 \%, 3.6 \%$ and $0.5 \%$, respectively. Tritiated testosterone was purchased from New England Nuclear (NET-187) (Boston, MA 02118, USA). The testosterone standard (4-androsten-17ß-ol-one) was purchased from Steraloids, Inc. ( $\$ 1734$ ) (Wilton, NH 03086, USA). Sensitivity of the assay, defined as the least amount of hormone that could be distinguished from zero, was $3.25 \mathrm{pg}$, or $65 \mathrm{pg} / \mathrm{ml}$ in a $50-\mu \mathrm{l}$ sample. Displacement of bound testosterone by increasing volumes of a peccary serum pool with a mean concentration of $1687 \mathrm{pg} / \mathrm{ml}$ was parallel to the standard curve. Recovery of radiolabelled testosterone averaged $88.6 \pm 7.8 \%$ in 7 assays and sample values were corrected for extraction efficiency. Intra- and inter-assay coefficients of variation were $9.0 \%$ and $15.0 \%$, respectively, for the peccary serum pool. 
Statistical analysis. Effect of date of collection on hormone concentrations, testicular measurements and seminal characteristics in captive adults was examined by an analysis of variance model for repeated measures using the General Linear Models (GLM) procedure of the Statistical Analysis System (SAS) (Helwig \& Council, 1979). Differences $(P<0.05)$ between means were isolated using Tukey's studentized range test. Testicular volume was estimated using the formula for a prolate spheroid (Beyer, 1976). Data from the only subadult boar were included following the first appearance of motile spermatozoa in his ejaculate in October 1983. In wild males, effect of season (summer, winter) and age (adult, subadult) were examined by two-way analysis of variance using SAS. Hormone concentrations during summer and winter seasons in wild and captive individuals were compared using Student's $t$ test. Simple correlation coefficients were calculated between body mass, testosterone, scrotal circumference, testicular volume, and selected seminal traits in all animals. Mean daily ambient temperature was averaged for the week before sampling and regressed on monthly mean reproductive traits.

\section{Results}

\section{Seasonal variation in serum testosterone and testicular measurements}

Serum testosterone concentrations in captive adult male peccaries varied significantly $(P<0.05)$ by date of collection and showed a definite seasonal trend (Fig. 1). Highest testosterone levels were observed from late October to late March $(1150-1450 \mathrm{pg} / \mathrm{ml})$ with lowest values recorded in August and September $(500-700 \mathrm{pg} / \mathrm{ml})$. Monthly testosterone values were higher and seasonal variation was more pronounced in individuals determined a priori to be dominant (Fig. 2). Seasonal variation was more pronounced in dominant males W2, W4, and W5 than in subordinate males W32 and W38. The single subadult (W40) sampled in captivity showed wide monthly fluctuations in testosterone concentrations until December 1983, after which serum testosterone levelled off at approximately $950 \mathrm{pg} / \mathrm{ml}$. This individual had reached sexual maturity by October 1983 (at age 16 months) based on semen analysis (see below).

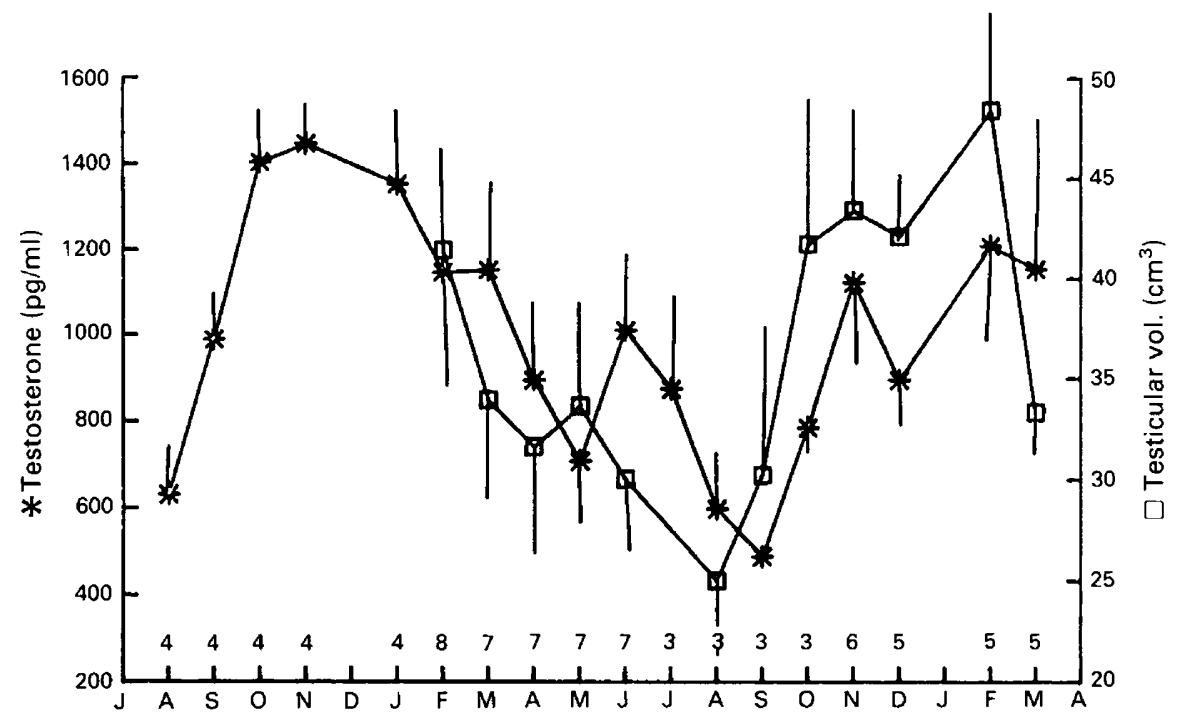

Fig. 1. Mean serum testosterone concentrations and estimated testicular volume in captive adult collared peccaries by date of collection. Vertical bars represent s.e.m. Sample size is above horizontal axis.

Serum testosterone concentrations in wild peccaries did not vary significantly $(P>0.05)$ by age or season, although seasonal values were higher in winter and concentrations in adults were higher than those in subadults (Table 1). Captive adults had slightly higher $(P=0.06)$ circulating 


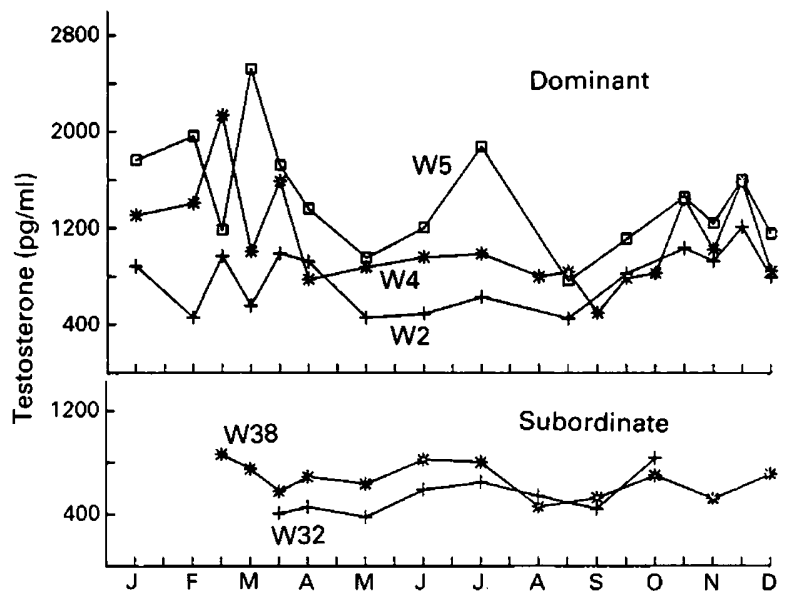

Fig. 2. Serum testosterone profiles in 3 dominant and 2 subordinate adult male collared peccaries.

testosterone levels (mean \pm s.e.m.) than did wild adults during winter (February-March) $(1164 \pm 128 \mathrm{pg} / \mathrm{ml}, \mathrm{N}=22$, vs $865 \pm 87 \mathrm{pg} / \mathrm{ml}, \mathrm{N}=22)$. Captive adults were heavier $(P<0 \cdot 05)$ than wild animals.

Table 1. Body weight and serum testosterone concentrations in wild male collared peccaries in south Texas by age and season (mean \pm s.e.m.)

\begin{tabular}{llrcc}
\hline Season & Age & No. & $\begin{array}{c}\text { Body } \\
\text { weight } \\
(\mathrm{kg})\end{array}$ & $\begin{array}{c}\text { Serum } \\
\text { testosterone } \\
\text { conc. } \\
(\mathrm{pg} / \mathrm{ml})\end{array}$ \\
\hline Winter & Adult & 22 & $19 \cdot 8 \pm 1 \cdot 0$ & $865 \pm 87$ \\
(February-March) & Subadult & 5 & $14 \cdot 5 \pm 1 \cdot 1$ & $666 \pm 205$ \\
& Juvenile & 1 & $5 \cdot 8$ & 92 \\
Summer & Adult & 16 & $21 \cdot 1 \pm 1 \cdot 4$ & $659 \pm 83$ \\
(July-August) & Subadult & 3 & $11 \cdot 6 \pm 1 \cdot 8$ & $368 \pm 67$ \\
Fall & Adult & 2 & $18 \cdot 9 \pm 1 \cdot 9$ & $773 \pm 251$ \\
(September-October) & & & & \\
\hline
\end{tabular}

Estimated testicular volume (Fig. 1) and monthly scrotal circumference in captive adults varied significantly $(P<0.05)$ by date of collection. Largest values occurred between late October and late February for both characteristics, while smallest values were recorded in summer months (Fig. 1). Average monthly scrotal circumference ranged from $182 \pm 12 \mathrm{~mm}$ (September 1983) to $228 \pm 8 \mathrm{~mm}$ (January 1983). Overall testicular dimensions were $28 \pm 2 \mathrm{~mm}$ wide and $49 \pm 3 \mathrm{~mm}$ long for all samples.

\section{Seasonal variation in semen characteristics in captive peccaries}

The 79 ejaculates obtained during monthly collections generally consisted of 3 fractions: a clear, accessory fluid fraction, a sperm-rich fraction, and a gel fraction. These fractions did not occur in all ejaculates and were not necessarily ejaculated in any particular order, although gel usually was 
collected at the end of the sampling procedure. Liquid volume (consisting of both clear and spermrich fluid) and total volume did not vary significantly $(P>0.05)$ by date of collection, whereas gel volume did vary significantly $(P<0.05)$. The 16 February 1984 ejaculates contained less gel than all other ejaculates, while the 13 September 1983 samples contained less gel than did the 14 December 1983 ejaculates. No seasonal trend was evident. Average ejaculate volumes for all ejaculates $(N=48)$ were $1.1 \pm 0.1 \mathrm{ml}$ liquid volume, $0.9 \pm 0.1 \mathrm{ml}$ gel volume, and $2.0 \pm 0.2 \mathrm{ml}$ total volume.

Evaluation of semen samples for motility revealed a weak $(P=0.06)$ monthly trend, with low levels in summer and high levels in spring. Motility in individual samples ranged from 5 to $90 \%$, with an overall means \pm s.e.m. of $57 \pm 15 \%$. Progressive motility, which is a visual estimate of rate of forward movement of live spermatozoa, generally was excellent in all samples and showed no differences $(P>0.05)$ by date of collection.

Average sperm concentration (spermatozoa/ml) and total sperm count for all ejaculates containing a sperm-rich fraction $(\mathrm{N}=48)$ were $371 \pm 30 \times 10^{6} / \mathrm{ml}$ and $596 \pm 96 \times 10^{6} /$ ejaculate, respectively. All males provided at least one sperm-rich ejaculate over the course of the study. Mean sperm concentration but not mean total sperm count (Fig. 3) varied $(P<0.05)$ by date of collection. Ejaculates from the 20 June 1983 sample were more concentrated than all other monthly sets of samples. Average monthly concentrations ranged from $132 \pm 22 \times 10^{6} / \mathrm{ml}$ (14 February $1983)$ to $828 \pm 204 \times 10^{6} / \mathrm{ml}(20$ June 1983$)$, while total sperm counts varied from $97 \pm 42 \times 10^{6} /$ ejaculate (14 February 1983) to $1406 \pm 449 \times 10^{6} /$ ejaculate (10 August 1983) (Fig. 3).

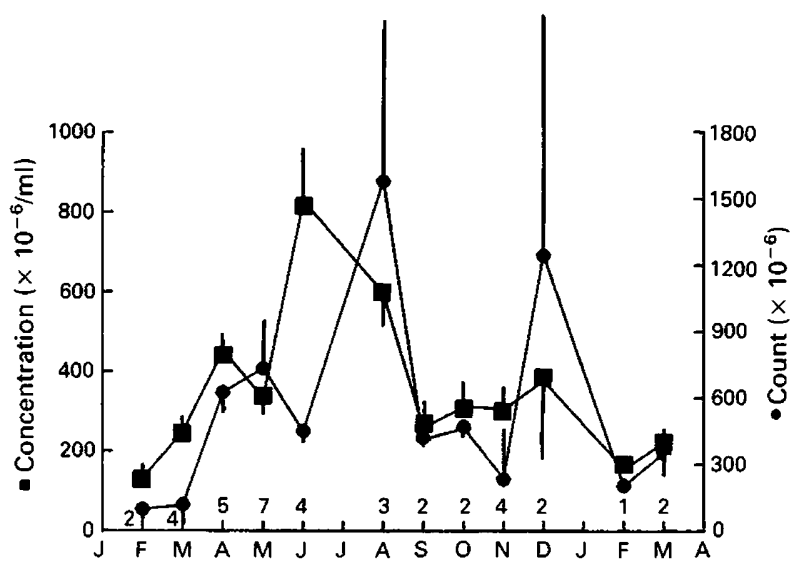

Fig. 3. Sperm concentration and total sperm count in ejaculates from captive collared peccaries by date of collection. Vertical bars represent s.e.m. Sample size is above horizontal axis.

Morphology of peccary spermatozoa varied widely between collections (Table 2). Percentage normal spermatozoa, percentage droplet abnormalities, and percentage tail abnormalities varied significantly $(P<0.01)$ by date of collection, but percentage head abnormalities was not significantly $(P>0.05)$ affected. Numbers of normal spermatozoa were lowest in the early fall months. In all ejaculates, normal spermatozoa, spermatozoa with head abnormalities, spermatozoa with droplet abnormalities and spermatozoa with tail abnormalities averaged $40 \cdot 2 \%, 0 \cdot 7 \%, 38 \cdot 8 \%$ and $20 \cdot 1 \%$, respectively.

Subadult male W40 provided a liquid-free, gelatinous ejaculate at 9 months of age, but there were no live spermatozoa in the ejaculate until approximately 15 months of age. The following month, W40 provided an ejaculate with normal adult characteristics (e.g. $292 \times 10^{6}$ spermatozoa $/ \mathrm{ml}$; $60 \%$ motility; 5 status). 
Table 2. Morphological characteristics of spermatozoa in 48 ejaculates of captive collared peccaries collected by electroejaculation (other abnormalities (detached heads, midpiece defects) occurred at $<1 \%$ in all months)

\begin{tabular}{|c|c|c|c|c|c|}
\hline \multirow[b]{2}{*}{$\begin{array}{l}\text { Date of } \\
\text { collection }\end{array}$} & \multirow[b]{2}{*}{ No. } & \multicolumn{4}{|c|}{ Sperm morphology $(\%)$} \\
\hline & & Normal & $\begin{array}{c}\text { Head } \\
\text { abnormalities* }\end{array}$ & $\begin{array}{c}\text { Droplet } \\
\text { abnormalities } \dagger\end{array}$ & $\begin{array}{c}\text { Tail } \\
\text { abnormalities }\end{array}$ \\
\hline 14 Feb. 1983 & 2 & $49 \cdot 5 \pm 14 \cdot 5^{\mathrm{abc}}$ & $N / A$ & $\mathrm{~N} / \mathrm{A}$ & $\mathrm{N} / \mathrm{A}$ \\
\hline 29 Mar. 1983 & 3 & $68 \cdot 0 \pm 4 \cdot 1^{\mathrm{ab}}$ & $1 \cdot 0 \pm 1 \cdot 0$ & $1.5 \pm 1.5^{c}$ & $29 \cdot 5 \pm 4 \cdot 3^{\mathrm{ab}}$ \\
\hline 27 Apr. 1983 & 5 & $24.6 \pm 10.0^{\mathrm{bc}}$ & $0.0 \pm 0.0$ & $34 \cdot 2 \pm 16 \cdot 8^{\mathrm{ab}}$ & $37 \cdot 6 \pm 10 \cdot 1^{\mathrm{a}}$ \\
\hline 24 May 1983 & 7 & $72 \cdot 1 \pm 7 \cdot 0^{\mathrm{a}}$ & $0 \cdot 1 \pm 0 \cdot 1$ & $12.1 \pm 5.0^{c}$ & $15 \cdot 3 \pm 3 \cdot 8^{\mathrm{ab}}$ \\
\hline 20 June 1983 & 4 & $53.3 \pm 11.9^{\mathrm{abc}}$ & $1.5 \pm 0.5$ & $29 \cdot 0 \pm 5.3^{\mathrm{ab}}$ & $15 \cdot 3 \pm 8 \cdot 3^{\mathrm{ab}}$ \\
\hline I0 Aug. 1983 & 6 & $44.5 \pm 5.8^{\mathrm{abc}}$ & $1.7 \pm 0.6$ & $33 \cdot 2 \pm 4 \cdot 6^{\mathrm{b}}$ & $20 \cdot 0 \pm 3 \cdot 5^{\mathrm{ab}}$ \\
\hline 13 Sep. 1983 & 4 & $16.0 \pm 3.9^{c}$ & $2 \cdot 0 \pm 2 \cdot 0$ & $64 \cdot 8 \pm 10 \cdot 6^{\mathrm{a}}$ & $17 \cdot 3 \pm 8 \cdot 8^{\mathrm{ab}}$ \\
\hline 7 Oct. 1983 & 4 & $16 \cdot 5 \pm 7 \cdot 0^{c}$ & $0.5 \pm 0.5$ & $80 \cdot 5 \pm 6 \cdot 3^{a}$ & $2 \cdot 5 \pm 1.3^{\mathrm{bc}}$ \\
\hline 2 Nov. 1983 & 4 & $14.5 \pm 3.4^{c}$ & $0.0 \pm 0.0$ & $40 \cdot 0 \pm 10 \cdot 3^{\mathrm{ab}}$ & $45 \cdot 5 \pm 12 \cdot 1^{2}$ \\
\hline 14 Dec. 1983 & 4 & $27.5 \pm 14.8^{\mathrm{bc}}$ & $0 \cdot 0 \pm 0 \cdot 0$ & $67 \cdot 5 \pm 14 \cdot 6^{\mathrm{a}}$ & $5.0 \pm 3.7^{\mathrm{bc}}$ \\
\hline 16 Feb. 1984 & 1 & 14 & 2 & 62 & 22 \\
\hline 21 Mar. 1984 & 3 & $46 \cdot 3 \pm 20 \cdot 6^{\mathrm{abc}}$ & $0.0 \pm 0.0$ & $44 \cdot 8 \pm 20 \cdot 2^{\mathrm{ab}}$ & $8 \cdot 8 \pm 0 \cdot 6^{\mathbf{a b}}$ \\
\hline
\end{tabular}

Values are mean \pm s.e.m.

Means within a column with different letters are significantly different $(P<0 \cdot 05)$.

*Head abnormalities: spermatozoa with acrosomal defects, micro- or macrocephaly. Did not differ significantly

$(P<0.05)$ by season.

†Droplet abnormalities: spermatozoa with proximal or distal protoplasmic droplets.

$\ddagger$ Tail abnormalities: spermatozoa with coiled tails, bent tails, or abaxial tail attachment.

\section{Correlations of selected reproductive traits in captive males}

Significant $(P<0.05)$ correlations were found between a number of selected physiological and anatomical traits. Body weight was correlated positively with scrotal circumference $(r=0 \cdot 71$, $P<0.001)$, testicular volume $(r=0.66, P<0.001)$, and serum testosterone concentration ( $r=0.43, P<0.001)$. Scrotal circumference $(r=0.60, P<0.01)$ and testicular volume $(r=0.37$, $P<0.01)$ were both correlated with serum testosterone. Semen characteristics of sperm concentration and total sperm count were correlated positively $(r=0.35, P<0.05)$ to each other, but not to any other characteristic. There was also a significant $(P<0.01)$ negative relationship between mean monthly testosterone levels and mean daily ambient temperature for 1 week before blood sampling (Fig. 4).

\section{Discussion}

Peak serum testosterone concentrations and testicular measurements in captive male collared peccaries occurred between October and March, coincidental with the peak breeding season of collared peccaries in South Texas, which ranges from late November to March (Low, 1970; Ellisor \& Harwell, 1979). Semen analyses indicated that spermatogenesis continued throughout the year with little change in sperm motility. Although monthly changes occurred in percentage normal spermatozoa, droplet and tail abnormalities, we feel that these changes may be an artefact of the electroejaculation technique (see below). Head abnormalities showed no detectable circannual rhythm. The male peccary may therefore be fertile all year, but decreased serum testosterone concentrations during summer may reduce libido and breeding activity (Ellisor \& Harwell, 1979).

The pattern of circulating testosterone in collared peccaries is of a lower amplitude than the cycle observed in seasonally breeding temperate-zone ungulate species such as white-tailed deer (Odocoileus virginianus) (Mirachi et al., 1978), Columbian black-tailed deer (Odocoileus hemionus 


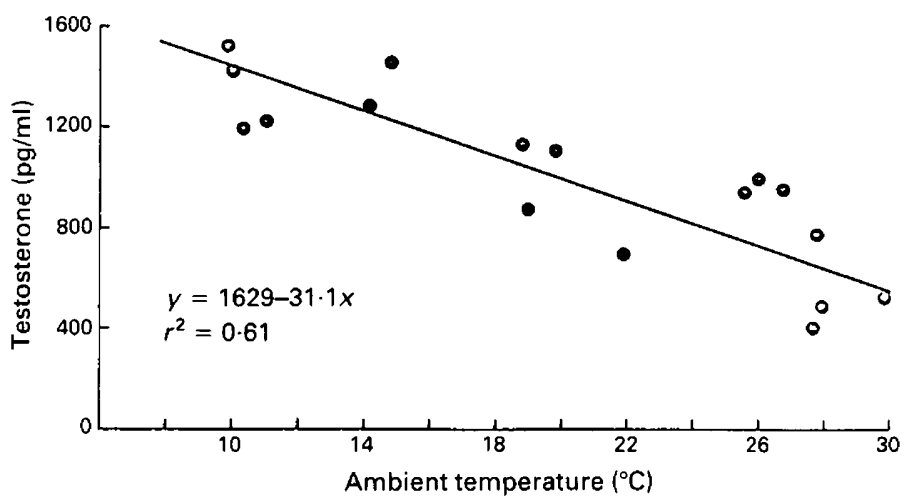

Fig. 4. Relationship between mean monthly serum testosterone concentrations in captive male collared peccaries and mean daily ambient temperature 1 week before blood sampling.

columbianus) (West \& Nordan, 1976), and red deer (Cervus elaphus) (Lincoln \& Kay, 1979). The peccary circannual rhythm is reminiscent of the annual profile in the male armadillo (Dasypus novemcinctus) (Czekala et al., 1980; Peppler \& Stone, 1981), a species, like the peccary, which has extended its range from tropical regions northward into warm temperate areas (McBee \& Baker, 1982). Seasonal changes in testosterone concentrations of armadillo (1-5- to 8-fold) are of a much smaller amplitude than in temperate-zone ungulates (10- to 20-fold) and reflect the lack of seasonal changes seen in testicular histology (Czekala et al., 1980).

Photoperiod appears to be the major environmental cue for regulating reproductive function in seasonally breeding temperate-zone species (Turek \& Campbell, 1979). The collared peccary originated in the tropics (Woodburne, 1968), where photoperiod is a less important cue. However, by extending its range into warm, semiarid regions of the American southwest, the peccary may have adjusted to seasonal environmental changes through physiological flexibility (Zervanos, 1975). Photoperiod changes thus may alter endogenous peccary neuroendocrine function. Changes in ambient temperature (which generally accompany photoperiod shifts) also could modify seasonal changes in male reproductive physiology and libido, as seen by the strong negative correlation between serum testosterone values and ambient temperature (Fig. 4).

Social factors may modify peccary neuroendocrine-gonadal function. Collared peccary herds exhibit dominance hierarchies (Sowls, 1966; Bissonette, 1982) with status positively correlated to size (Bissonette, 1982). In the present captive herd, dominant males were largest in body weight, the most successful breeders, and had higher concentrations of testosterone than subordinates (Fig. 2). A lack of a cyclic pattern in testosterone concentrations in subordinate males W32 and W38 (Fig. 2) was associated with low social rank.

The presence of oestrous females also may modify seasonal changes in serum testosterone. During the present study, males had visual, olfactory and tactile contact (through a fence) with oestrous females before only three sampling periods (October 1982, November 1982 and June 1983). At all other times, sexes were isolated by at least $10 \mathrm{~m}$. Mean testosterone concentrations were highest during October and November 1982 and showed a transient rise in June 1983 (Table 1).

Copulation or proximity of receptive females has been associated with rises in LH and testosterone in many species, including the domestic boar (Liptrap \& Raeside, 1978). An acute testosterone rise, with an associated surge in libido, may be highly adaptive by allowing breeding of females which resume cycling after parturition during summer months.

Testosterone concentrations in male peccaries are comparable to those reported for domestic boars, which range from 1 to $8 \mathrm{ng} / \mathrm{ml}$, depending upon breed and handling procedure (Ellendorff $e t$ 
al., 1975; Claus \& Gimenez, 1977; Edqvist et al., 1980). A significant problem associated with assaying serum testosterone in one sample per month, as in the present study, may be pulsatile hormone release. Pulsatile secretion of testosterone has been reported in many domestic species, including pigs (Sanford et al., 1976; Claus \& Gimenez, 1977), and in wild ungulates such as red deer (Lincoln \& Kay, 1979). In domestic boars, elevations in testosterone concentrations can occur within $60 \mathrm{~min}$ (Sanford et al., 1976). Testosterone pulse duration ranged from 1 to $3 \mathrm{~h}$, with $2-4$ pulses occurring daily, and pulses generally were preceded by large or multiple releases of LH. The serum testosterone concentration in dominant male W5 during the 4 August 1983 sample (Fig. 2) may have been taken during a pulse. Further work is necessary to confirm a pulsatile pattern of testosterone release in the peccary and to describe individual and circannual variation in pulse amplitude, duration and frequency. As suggested by Wesson et al. (1979), large sample sizes may be necessary to determine accurate androgen concentrations in wild populations unless frequent blood samples are collected for longer sampling periods.

Semen characteristics have not been published previously for the collared peccary. Sowls (1966) reported collection of sperm-rich ejaculates by electroejaculation from 2 males. Sperm concentration of peccary semen samples is comparable to that of domestic boar semen, which ranges from 100 to $500 \times 10^{6}$ spermatozoa/ml (Swierstra \& Rahnefeld, 1966; Cameron, 1980; Gibson \& Johnson, 1980). Although not demonstrated directly, peccary semen collected in the present study was judged adequate for fertilization throughout the year based on normal semen values seen in the pig (Larsson, 1986). Low (1970) reached the same conclusion based on sperm counts in histological sections of seminiferous tubules.

Deposition of large amounts of gelatinous material was observed in female peccaries after copulation. Two gel plugs which dropped from the vulva and were collected had volumes of 45 and $80 \mathrm{ml}$, respectively. Sowls (1966) also reported the presence of large gel plugs following copulation and stated that the large male bulbourethral glands were the source of this material. The reason that such large gel volumes were not collected in the present study may be that electroejaculation generally produces little gel. Ejaculates collected by electroejaculation in domestic pigs are characterized by lower gel volume $(<5.0 \mathrm{ml} /$ ejaculate) and liquid volume (Vera Cruz, 1959; Clark, 1976) than those collected by the more commonly used gloved-hand method. These observations suggest that a natural peccary ejaculate contains more gel volume and possibly more liquid volume than we observed.

Analysis of peccary spermatozoa revealed a high percentage of morphological defects. However, numbers of head abnormalities, which occur primarily during spermatogenesis, were within normal ranges for domestic boar spermatozoa (Gibson \& Johnson, 1980). The average of $40 \cdot 2 \%$ normal spermatozoa is much lower than the $70 \%$ figure quoted for domestic boar semen (Singleton \& Shelby, 1972; Gibson \& Johnson, 1980). The physiological significance of the seasonal variations in percentage morphologically normal spermatozoa that we observed are difficult to interpret. A high incidence of distal protoplasmic droplets, which were the most common abnormality, is not diagnostic of lowered fertility (Larsson, 1986). In domestic boars, a high incidence of distal droplets is also observed at low-serving frequency (Crabo, 1986), following electroejaculation (Vera Cruz, 1959), and under conditions of incomplete collection (Hurtgen et al., 1980). Each of these situations occurred in the present study. Bent and coiled tails may have resulted from handling procedures or cold shock, although precautions were taken to avoid such damage; while abaxial tail attachment is not considered an abnormality in boars (Larsson, 1986) and may not be in the peccary. We conclude from this evidence that the lack of seasonal changes on sperm head abnormalities is probably more diagnostic of year-round fertility than the observed changes in percentage normal spermatozoa.

The reproductive role of the male peccary is primarily to complement changes in female reproductive function. Low (1970) and the present study demonstrated indirectly that males are fertile all year. The relationship of circulating testosterone concentrations to ambient temperature and season noted in the present study suggests a male facultative reproductive quiescence during the 
late summer. Low male libido combined with female lactational anoestrus could account for the lack of breeding seen during the summer months (Ellisor \& Harwell, 1979). During drought years, nutritional stress may reduce male breeding activity to mirror female acyclicity (Lochmiller, 1984). During good years, when females are on a high nutritional plane and cyclic through the summer, male breeding activity may still be reduced due to high temperatures. If dominant males do perform most of the breeding (Bissonette, 1982), temperature-induced low libido of these alpha males could have a significant effect on herd population dynamics. Questions which need further study include examination of the short-term gonadal and behavioural responsiveness to seasonal (e.g. photoperiod), social (e.g. presence of cyclic females, dominance relationships), and nutritional factors in male collared peccaries.

This research was supported by the National Rifle Association of America and the Caesar Kleberg Research Program in Wildlife Ecology, Department of Wildlife and Fisheries Sciences, Texas A\&M University. We thank the personnel of the Chaparosa Ranch, La Pryor, Texas and the Chaparral Wildlife Management Area, Artesia Wells, Texas for providing research animals; P. J. Ettestad, T. G. Biediger, R. E. Hoekstra and J. R. Jackson for assistance with animal handling and semen collection; L. A. Rund for help with testosterone assays; and J. Packard and 2 anonymous reviewers for improving the manuscript.

\section{References}

Abraham, G.E., Swerdloff, R., Tulchinsky, D. \& Odell, W.D. (1971) Radioimmunoassay of plasma progesterone. J. clin. Endocr. Metab. 31, 619-624.

Beyer, W.H. (1976) Standard Mathematical Tables, 24th edn. CRC Press, Cleveland.

Bissonette, J.A. (I982) Ecology and social behavior of the collared peccary in Big Bend National Park. USDI Nat. Park Serv. Sci. Mono. Ser. No. 16.

Cameron, R.D.A. (1980) Factors influencing semen production and quality in young boars. Proc. Int. Pig Veterinary Society 34.

Clark, T.L. (1976) Electroejaculation in the anesthetized and nonanesthetized boar. Proc. Int. Pig. Veterinary Society D14.

Claus, R. \& Gimenez, T. (1977) Diurnal rhythm of $5 \alpha$ androst-16-en-3-one and testosterone in peripheral plasma of boars. Acta endocr., Copenh. 84, 200-206.

Crabo, B.G. (1986) Factors affecting spermatogenesis and boar fertility. In Current Therapy in Theriogeno$\log y I I$, pp. 975-978. Ed. D. A. Morrow. W. B. Saunders Co., Philadelphia.

Czekala, N.M., Hodges, G.E., Gause, G.E. \& Lasley, B.L. (1980) Annual circulating testosterone levels in captive and free-ranging male armadillos (Dasypus novemcinctus). J. Reprod. Fert. 59, 199-204.

Edqvist, C.E., Einarsson, S., Larsson, K. \& Lundstrom, K. (1980) Diurnal variation in peripheral plasma levels of testosterone, androsterone, and cortisol in boars. Acta vet. scan. 21, 451-453.

Ellendorff, F., Parvizi, N., Poeranta, D.K., Hartjen, A., Konig, A., Smidt, D. \& Elsaesser, F. (1975) Plasma luteinizing hormone and testosterone in the adult male pig: 24 hour fluctuations and the effect of copulation. J. Endocr. 67, 403-410.

Ellisor, J.E. \& Harwell, F. (1979) Ecology and management of javelina in south Texas. Texas Parks and Wildl. Fep. FA Rep. Serv. No. 16.

Gibson, C.D \& Johnson, D.C. (1980) Evaluation of the boar for breeding soundness. In Current Therapy in Theriogenology, pp. 1034-1037. Ed. D. A. Morrow, W. B. Saunders Co., Philadelphia.

Hellgren, E.C., Lochmiller, R.L., Amoss, Jr. M.S. \& Grant, W.E. (1985) Serum progesterone, estradiol17B, and glucocorticoids in the collared peccary during gestation and lactation as influenced by dietary protein and energy. Gen. comp. Endocrinol. 59, 358-368.

Helwig, J.H. \& Council, K.A. (1979) SAS Users guide. SAS Inst., Inc. Raleigh, N.C.

Hurtgen, J.P., Larsen, R. \& Crabo, B. (1980) Factors affecting semen quality in the boar. Proc. Int. Pig Veterinary Society 35.

Kirkpatrick, R.D. \& Sowls, L.K. (1962) Age determination of the collared peccary by the toothreplacement pattern. J. Wildl. Mgmi 26, 214-217.

Larsson, K. (1986) Evaluation of boar semen. In Current Therapy in Theriogenology II, pp. 972 975. Ed. D.A. Morrow. W. B. Saunders Co., Philadelphia.

Lincoln, G.A. \& Kay, R.N.B. (1979) Effects of season on the secretion of $\mathrm{LH}$ and testosterone in intact and castrated red deer stags (Cervus elaphus). J. Reprod. Fert. 55, 75-80.

Liptrap, R.M. \& Raeside, J.I. (1978) A relationship between plasma concentrations of testosterone and corticosteroids during sexual and aggesssive behavior in the boar. $J$. Endocr. 76, 75-85.

Lochmiller, R.L. (1984) Nutritional influences on growth and reproduction and physiological assessment of nutritional status in the collared peccary. $\mathrm{Ph} . \mathrm{D}$. thesis, Texas A\&M University.

Lochmiller, R.L. \& Grant, W.E. (1983) A sodium bicarbonate-acid powered blow-gun syringe for remote injection of wildlife. J. Wildl. Dis. 19, 48-51.

Lochmiller R.L., Hellgren, E.C. \& Grant, W.E. (1984a) Techniques for collecting blood from collared peccaries (Dicotyles tajacu L.). J. Wildl. Dis. 20, 47-50. 
Lochmiller, R.L., Hellgren, E.C. \& Grant, W.E. (1984b) Selected aspects of collared peccary (Dicotyles tajacu) reproductive biology. Zoo Biol. 3, 145-149.

Lochmiller, R.L., Hellgren, E.C., Varner, L.W., Greene, L.W., Amoss, M.S., Jr, Seager, S.W.J. \& Grant, W.E. (1985) Physiological responses of the adult collared peccary to severe nutritional restriction. Comp. Biochem. Physiol. 82A, 49-58.

Lochmiller, R.L., Hellgren, E.C. \& Grant, W.E. (1986) Reproductive responses to nutritional stress in adult female collared peccaries. J. Wildl. Mgmt 50, 295-300.

Low, W.A. (1970) The influence of aridity on reproduction of the collared peccary (Dicotyles tajacu (Linn)) in Texas. Ph.D. thesis, University of British Columbia.

McBee, K. \& Baker, R.J. (1982) Dasypus novemcinctus. Mamm. Species 162, 1-9.

Mirarchi, R.E., Howland, B.E., Scanlon, P.F., Kirkpatrick R.L. \& Sanford, L.M. (1978) Seasonal variation in plasma LH, FSH, prolactin, and testosterone concentrations in adult male white-tailed deer. Can. $J$. Zool. 56, 121-127.

Peppler, R.D. \& Stone, S.C. (1981) Annual pattern in plasma testosterone in the male armadillo, Dasypus novemcinctus. Anim. Reprod. Sci. 4, 49-53.

Sanford, L.M., Swierstra, E.E., Palmer, W.M. \& Howland, B.E. (1976) The profile of luteinizing hormone and testosterone secretion in the board. Proc. 8th Int. Cong. Anim. Reprod. \& A.I., Krakow 3, 96-99.

Schweinsburg, R.E. \& Sowls, L.K. (1972) Aggressive behavior and related phenomena in the collared peccary. Z. Tierpsychol. 30, 132-145.

Seager, S.W.J., Hellgren, E.C., Magyar, S.J., Biediger, T.G., Hoekstra, R.E., Coscarelli, K.P., Lochmiller, R.L. \& Grant, W.E. (1984) Semen collection in the javelina or collared peccary (Tayassu tajacu). In Proc. Am. Assoc. Zoo Vet., Louisville, p. 185, Abstr.

Singleton, W.L. \& Shelby, D.R. (1972) Variation among boars in semen characteristics and fertility. J. Anim. Sci. 34, 762-766.

Smith, N.S. \& Sowls, L.K. (1975) Fetal development of the collared peccary. J. Mammal. 56, 619-625.
Sowls, L.K. (1966) Reproduction in the collared peccary. Symp. zool. Soc. Lond. 15, 155-172.

Sowls, L.K. (1974) Social behavior of the collared peccary (Dicotyles tajacu). In The Behavior of Ungulates and Its Relation to Management, pp. 144-165. Eds V. Geist \& F. Walther. IUCN, Morges.

Swierstra, E.E. \& Rahnefeld, R.W. (1966) Semen and testis characteristics in young Yorkshire and Lacombe boars. J. Anim. Sci. 26, 149-157.

Turek, F.W. \& Campbell, C.S. (1979) Photoperiodic regulation of neuroendocrine-gonadal activity. Biol. Reprod. 20, 32-50.

Vera Cruz, N.C. (1959) Artificial insemination in pigs. I. Semen collection by electrical stimulation in boars. Phillip. Agric. 43, 225-235.

Wesson, J.A., Scanlon, P.F., Kirkpatrick, R.L., Mosby, H.S. \& Butcher, R.L. (1979) The influence of chemical immobilization and physical restraint on steroid hormone levels in blood of white-tailed deer. Can. $J$. Zool. 57, 768-776.

West, N.O. \& Nordan, H.C. (1976) Hormonal regulation of reproduction and the antler cycle in the male Columbian black-tailed deer (Odocoileus hemionus columbianus). Part I. Seasonal changes in the histology of the reproductive organs, serum testosterone, sperm production, and the antler cycle. Can. J. Zool. 54, 1617-1636.

Wislocki, G.B. (1931) Notes on the female reproductive tract (ovaries, uterus, and placenta) of the collared peccary (Pecari angulatus Bangsi Goldman). $J$. Mammal. 12, 143-149.

Woodburne, M.O. (1968) The cranial myology and osteology of Dicotyles tajacu, the collared peccary, and its bearing on classification. Memoirs South. Calif. Acad. Sci. 7, $1-48$.

Zervanos, S.M. (1975) Seasonal effects of temperature on the respiratory metabolism of the collared peccary (Tayassu tajacu). Comp. Biochem. Physiol. 50A, 365-371.

Received 2 August 1988 